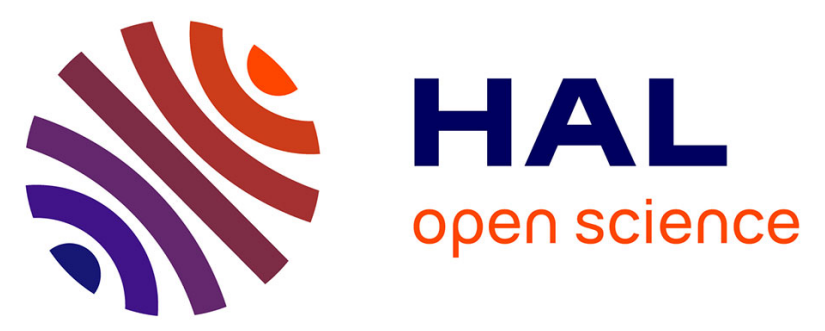

\title{
NEW SUPERCONDUCTING OXIDES IN THE Bi-Sr-Ca-Cu-O SYSTEM : MAGNETIC MEASUREMENTS AND STRUCTURAL DETERMINATION
}

Pierre Bordet, J. Capponi, C. Chaillout, J. Chenavas, B. Giordanengo, M. Godinho, A. Hewat, E. Hewat, J. Hodeau, P. Lejay, et al.

\section{To cite this version:}

Pierre Bordet, J. Capponi, C. Chaillout, J. Chenavas, B. Giordanengo, et al.. NEW SUPERCONDUCTING OXIDES IN THE Bi-Sr-Ca-Cu-O SYSTEM : MAGNETIC MEASUREMENTS AND STRUCTURAL DETERMINATION. Journal de Physique Colloques, 1988, 49 (C8), pp.C8-2111-C82112. 10.1051/jphyscol:19888949 . jpa-00229228

\section{HAL Id: jpa-00229228 https://hal.science/jpa-00229228}

Submitted on 1 Jan 1988

HAL is a multi-disciplinary open access archive for the deposit and dissemination of scientific research documents, whether they are published or not. The documents may come from teaching and research institutions in France or abroad, or from public or private research centers.
L'archive ouverte pluridisciplinaire HAL, est destinée au dépôt et à la diffusion de documents scientifiques de niveau recherche, publiés ou non, émanant des établissements d'enseignement et de recherche français ou étrangers, des laboratoires publics ou privés. 


\title{
NEW SUPERCONDUCTING OXIDES IN THE Bi-Sr-Ca-Cu-O SYSTEM: MAGNETIC MEASUREMENTS AND STRUCTURAI DETERMINATION
}

P. Bordet, J. J. Capponi, C. Chaillout, J. Chenavas, B. Giordanengo ${ }^{1}$, M. Godinho' ${ }^{1}$ A. W. Hewat ${ }^{2}$, E. A. Hewat ${ }^{3}$, J. L. Hodeau, P. Lejay ${ }^{1}$, M. Marezio ${ }^{4}$, P. De Rango ${ }^{1}$, A. M. Spieser, A. Sulpice ${ }^{1}$, J. L. Tholence ${ }^{1}$, R. Tournier ${ }^{1}$ and D. Tranqui

Laboratoire de Cristallographie, CNRS, associé à l'U.J.F.-G., 166X, 38042 Grenoble Cedex, France

\begin{abstract}
Detailed neutron diffraction structure analysis of $\mathrm{Bi}_{2} \mathrm{Sr}_{2} \mathrm{CaCu}_{2} \mathrm{O}_{8}$ is reported. The effects of $\mathrm{Pb}$-substitution on $\mathrm{Bi}_{2} \mathrm{Sr}_{2} \mathrm{CaCu}_{2} \mathrm{O}_{8}$ and $\mathrm{Bi}_{2} \mathrm{Sr}_{2} \mathrm{CuO}_{6}$ are discussed, and magnetization measurement results on the $110 \mathrm{~K}$ phase in the $\mathrm{Bi}-\mathrm{Sr}-\mathrm{Ca}-\mathrm{Cu}-\mathrm{O}$ system are given.
\end{abstract}

Since the discovery of high $T_{c}$ superconductivity in the Bi-Sr-Ca-Cu-O system [1], two superconducting phases have been unambiguously identified, namely $\mathrm{Bi}_{2} \mathrm{Sr}_{2} \mathrm{CuO}_{6}\left(T_{\mathrm{c}} \approx 10 \mathrm{~K}\right)$ and $\mathrm{Bi}_{2} \mathrm{Sr}_{2} \mathrm{CaCu}_{2} \mathrm{O}_{8}$ $\left(T_{c} \approx 80 \mathrm{~K}\right)$, hereafter denoted as 2201 and 2212 . The presence of transition temperatures around $110 \mathrm{~K}$ in mixed phase samples suggested the existence of a third phase, the composition of which could be 2223, based on an analogy with the later discovered thallium compounds [2]. We report here a detailed structural analysis of the 2212 phase and physical characterizations of the $110 \mathrm{~K}$ phase.

Three alternative models for the structure of $\mathrm{Bi}_{2} \mathrm{Sr}_{2} \mathrm{CaCu}_{2} \mathrm{O}_{8}$ were first proposed on the basis of $\mathrm{X}$ ray single crystal diffraction data [3]. Then, Bordet et al. [4] used powder neutron diffraction to show that the double Bi-O layers do not adopt the usual $\mathrm{Au}$ rivilius structure, but are arranged in an $\mathrm{NaCl}$-type structure. The problem with this model, refined in the Fmmm space group, is that the in-plane $\mathrm{Bi}-\mathrm{O}$ distances are too long to satisfy the normal $\mathrm{Bi}^{3+}$ coordination. In fact, these oxygens appear disordered in this model. We show here a more precise analysis of our neutron data allowing a better determination of the $\mathrm{Bi}$ co-ordination.

As the space group Amaa or its non-centric subgroup A2aa have been confirmed by convergent beam electron diffraction [5], the neutron data were refined in Amaa by permitting all atoms to move off the $y$-axis special position of the Bordet et al. structure taken as. the starting model. Only the BiO plane oxygen $\mathrm{O} 3$ (which appeared "disordered" in Fmmm) was much displaced. In Amaa, the best refinement was obtained by splitting $\mathrm{O} 3$ between two sites either side of the center of the Bi-square. In an attempt to remove the need for split atoms, we simply removed the center of symmetry (space group A2aa). O3 was then not constrained in any way, and immediately moved to occupy a position close to a pair of $\mathrm{Bi}$ atoms. As these refinements were carried out in the subcell, they cannot take into account the displacements of the $\mathrm{Bi}$ atoms related to the existence of the $\approx 4.7 \AA$ superstructure along the $a$-axis.

In the resulting structure (see Tab. I), each $\mathrm{Bi}$ has three close oxygen neighbours at between $2.12 \AA$ and $2.28 \AA$, opposite to the $\mathrm{Bi}^{3+}$ "lone pair" . This coordination is more satisfactory than that obtained with $\mathrm{Fmmm}$, and all $\mathrm{Bi}$ remains essentially $\mathrm{Bi}^{3+}$, as there is no experimental evidence for $\mathrm{Bi}^{5+}$. The formula is close to $\mathrm{Bi}_{2} \mathrm{Sr}_{2} \mathrm{CaCu}_{2} \mathrm{O}_{8}$

The substitution of $\mathrm{Bi}$ by $\mathrm{Pb}$ in the 2201 and 2212 phases as also been studied. It was found in both cases that as much as $0.4 \mathrm{~Pb}$ per unit formula can be incorporated without detection of extra phases by X-ray powder diffraction. Preliminary a.c. susceptibility measurements on powder and single crystal samples of both phases have been performed. They seem

Table I. - Atom positions, thermal and occupancy factors, $\mathrm{Bi}-\mathrm{O}$ and $\mathrm{Cu}-\mathrm{O}$ distances $(\AA)$ for $\mathrm{Bi}_{2} \mathrm{Sr}_{2} \mathrm{CaCu}_{2} \mathrm{O}_{8}$.

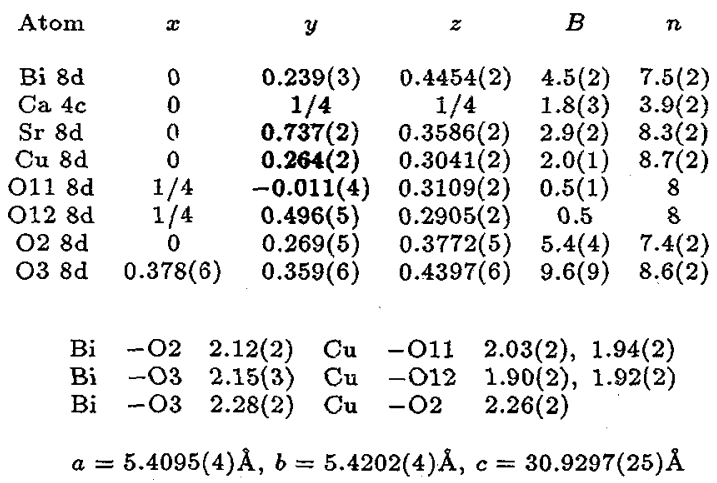

${ }^{1}$ C.R.T.B.T., CNRS, 166X, 38042 Grenoble Cedex, France.

${ }^{2}$ Institut Laue-Langevin, 156X, 38042 Grenoble Cedex, France.

${ }^{3} \mathrm{CEA}$, IRDI, D. LETI, CENG, 85X, 38041 Grenoble, France.

${ }^{4}$ Also at AT\& T Bell Laboratories, Murray Hill, NJ 07974, U.S.A. 
to indicate an increase of $T_{c}$ for the $\mathrm{Pb}$-substituted 2201 phase, and $\mathrm{a} \approx 100 \mathrm{~K}$ transition for the $\mathrm{Pb}$ substituted 2212 samples (Fig. 1). X-ray precession photographs and electron diffraction studies reveal the presence of superstructures for both phases which are different from those observed with the corresponding unsubstituted compounds.

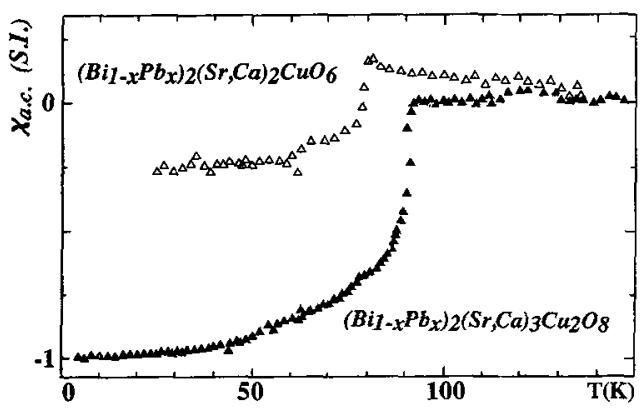

Fig. 1. - A.c. susceptibility curves for $\mathrm{Pb}$ substituted 2212 and 2201 polycristalline samples.

It is now confirmed that a series of superconducting compounds of formula $\mathrm{Bi}_{2} \mathrm{Sr}_{2} \mathrm{Ca}_{n-1} \mathrm{Cu}_{n} \mathrm{O}_{4+2 n}$ exits with $n=1,2,3$. A crystal of the $n=3$ phase has been observed to be superconducting at $103 \mathrm{~K}$ [2]. This result confirms other analyses which have shown the presence of a minor phase of this composition in superconducting samples containing simultaneously the major phase 2212 with a $T_{c}$ of $85 \mathrm{~K}$ and a small fraction of the sample having a transition around $110 \mathrm{~K}$ [6].

We have prepared samples starting from different compositions of $\mathrm{Bi}_{2} \mathrm{O}_{3}, \mathrm{SrCO}_{3}, \mathrm{CaCO}_{3}$ and $\mathrm{CuO}$ at different firing temperatures and annealing times. The largest fraction of the superconducting phase having a $T_{c}$ of $110 \mathrm{~K}$ that we have obtained reaches $15 \%$ of the sample volume. The powders of initial composition $\mathrm{Bi}_{2} \mathrm{Sr}_{1.5} \mathrm{Ca}_{1.5} \mathrm{Cu}_{2} \mathrm{O}_{8}$ were fired at $800{ }^{\circ} \mathrm{C}$ for 12 hours in air and after grinding, a second firing of 12 hours at $865^{\circ} \mathrm{C}$ in oxygen was applied to the pressed pellets. A fraction of about $1 \%$ of superconducting phase at $110 \mathrm{~K}$ was obtained. By annealing in oxygen at $880^{\circ} \mathrm{C}$ for 48 hours, this fraction has increased up to $15 \%$.

The Meissner and the screening effects are always identical between $90 \mathrm{~K}$ and $110 \mathrm{~K}$ as observed in figure 2 in all our samples. This property shows that the superconductivity observed below $110 \mathrm{~K}$ takes place in a well-crystallized phase, in agreement with other findings. No enhancement of $H_{c_{1}}$ is observed. Then, this superconductivity is established in crystallites having dimensions larger than the London penetration depth. The reversibility of the magnetization versus field and temperature gives us the opportunity of studying the thermodynamical properties of this phase. The condensation energy is given by the area under the mag- netization curve:

$$
\int_{0}^{H_{\mathrm{c}_{2}}}\left(M_{\mathrm{s}}-M_{n}\right) \mathrm{d} H=-H_{\mathrm{c}}^{2} / 8 \pi
$$

A minimum value for this area can be extrapolated in high fields at different temperatures. The volume fraction of the sample having $T<T_{\mathrm{c}}<T+\mathrm{d} T$ is assumed to be $\mathrm{d} T / T_{\mathrm{c}_{0}}$ with $T_{\mathrm{c}_{0}}=110 \mathrm{~K}$. This distribution leads to a linear decrease of the superconducting volume with temperature as observed in figure 2 . If the thermodynamical critical field is assumed to vary as $H_{\mathrm{c}}=H_{0}\left(1-\left(T / T_{\mathrm{c}}\right)^{2}\right)$, there is a simple relation between the specific heat coefficient $\gamma, T_{\mathrm{c}}$ and $H_{0}: H_{0}^{2}=$ $2 \pi \gamma T_{c}^{2}$. Assuming that the particles of the distribution have the same $\gamma$ but different $T_{\mathrm{c}}$ 's, we can calculate using this distribution the mean square of $H_{\mathrm{c}}$ :

$$
H_{\mathrm{c}}^{2}=2 \gamma / T_{\mathrm{c}_{0}}\left(T_{\mathrm{c}_{0}}^{3} / 3-2 T^{2} T_{\mathrm{c}_{0}}-T^{4} / T_{\mathrm{c}_{0}}^{4}+8 / 3 T^{3} / T_{\mathrm{c}_{0}}^{3}\right) \text {. }
$$

We have determined a minimum of $H_{c}^{2}$ at different temperatures, and deduced a minimum $\gamma$ value of about $10 \mathrm{~mJ} /$ mole. $\mathrm{K}^{2}$ using the magnetization curves obtained at 100,95 and $90 \mathrm{~K}$. Such a $\gamma$ value is similar to that already evaluated for the 2212 phase from specific heat measurements around $85 \mathrm{~K}$ [7].

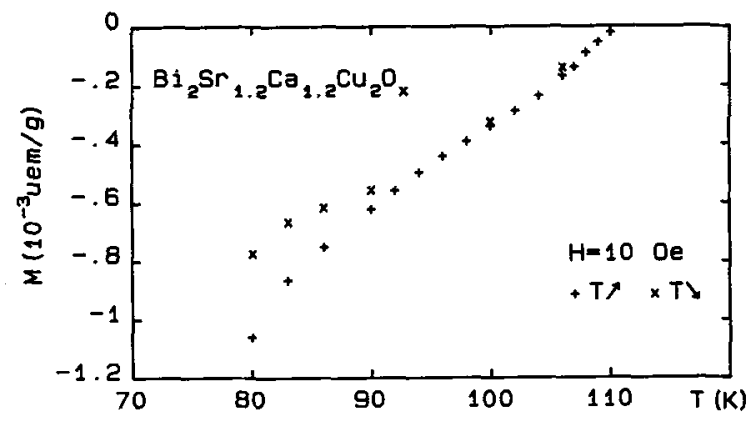

Fig. 2. - The zero-field cooled susceptibility $(+)$ and the field-cooled susceptibility $(x)$ in 10 Oe plotted versus temperature. The increase of the superconducting volume below $85 \mathrm{~K}$ is due to the "2212" phase. The total susceptibility of this powder sample corresponds to $\approx 70 \%$ of superconducting volume at $4 \mathrm{~K}$.

[1] Maeda, H. et al., to appear in J.J.A.P. Lett. 27, 2 (1988);

Michel, C. et al., Z. Phys. B 68 (1987) 421.

[2] Tarascon, J. M. et al. (1988) preprint.

[3] Subramanian, M. A. et al., Science 239 (1988) 1015;

Sunshine, S. A. et al. (1988) preprint;

Tarascon, J. M. et al., Phys. Rev. (1988) in press.

[4] Bordet, P. et al., Physica $C$ (1988) in press.

[5] Withers, R. L. et al., J. Phys. C 21 (1988) L417.

[6] Tallon, J. L. et al., Nature 333 (1988) 153;

Zandbergen, H. W. et al., Nature 332 (1988) 620.

[7] Fisher, R. A. et al. (1988) preprint. 